\title{
FOXO3 wt Allele
}

National Cancer Institute

\section{Source}

National Cancer Institute. FOXO3 wt Allele. NCI Thesaurus. Code C52907.

Human FOXO3 wild-type allele is located in the vicinity of $6 \mathrm{q} 21$ and is approximately 121 $\mathrm{kb}$ in length. This allele, which encodes forkhead box protein O3A, plays a role in the activation of both transcription by RNA polymerase II and apoptosis that is induced by oxidative stress. 